\title{
A Review of Clinical Practice Guidelines and Treatment Recommendations for Cancer Care in the COVID-19 Pandemic
}

\author{
Alberto Zaniboni ${ }^{1}$, Michele Ghidini ${ }^{2}$ (D), Francesco Grossi ${ }^{2}$, Alice Indini ${ }^{2}$ (D), \\ Francesca Trevisan ${ }^{3}$, Alessandro Iaculli ${ }^{4}$, Lorenzo Dottorini ${ }^{4}$ (D), Giovanna Moleri ${ }^{5}$, \\ Alessandro Russo ${ }^{6}$, Ivano Vavassori ${ }^{7}$, Alessandra Brevi ${ }^{8}$, Emanuele Rausa ${ }^{9} \mathbb{D}$, Luigi Boni ${ }^{10}$, \\ Daniele Dondossola ${ }^{11,12}$, Nicola Valeri ${ }^{13,14}$, Antonio Ghidini ${ }^{15}$ (D) Gianluca Tomasello ${ }^{2}$ \\ and Fausto Petrelli 16,*1D
}

1 Oncology Unit, Fondazione Poliambulanza, 25124 Brescia, Italy; azaniboni@alice.it

2 Oncology Unit, Fondazione IRCCS-Ca' Granda, Ospedale Maggiore Policlinico Milan, 20122 Milan, Italy; mghido@hotmail.it (M.G.); fg1965@libero.it (F.G.); alice.indini@gmail.com (A.I.);

gianluca.tomasello@gmail.com (G.T.)

3 Radiotherapy Unit, ASST Bergamo Ovest, 24047 Treviglio (BG), Italy; trevisan.francesca1@gmail.com

4 Oncology Unit, ASST Bergamo Est, 24068 Seriate (BG), Italy; aleiaculli@gmail.com (A.I.);

ldottorini@gmail.com (L.D.)

5 Centro Servizi, Direzione Socio-Sanitaria, ASST Bergamo Ovest, 24047 Treviglio (BG), Italy; giovanna.moleri@libero.it

6 Surgical Oncology Unit, ASST Bergamo Ovest, 24047 Treviglio (BG), Italy; alessandrorusso70@yahoo.it

7 Urology Unit, ASST Bergamo Ovest, 24047 Treviglio (BG), Italy; ivano.vavassori0@alice.it

8 Otorhinolaryngology-Head and Neck Surgery Unit, ASST Bergamo Ovest, 24047 Treviglio (BG), Italy; brevialessandra@gmail.com

9 General Surgery 1 Unit, ASST Papa Giovanni XXIII, 24127 Bergamo, Italy; emarausa@yahoo.it

10 Department of Surgery, Fondazione IRCCS-Ca' Granda, Ospedale Maggiore Policlinico, University of Milan, 20122 Milan, Italy; luigi.boni@policlinico.mi.it

11 General and Liver Transplant Surgery Unit, Fondazione IRCCS-Ca' Granda, Ospedale Maggiore Policlinico Milan, 20122 Milan, Italy; daniele.dondossola@policlinico.mi.it

12 Department of Pathophysiology and Transplantation, Università degli Studi of Milan, 20122 Milan, Italy

13 Division of Molecular Pathology and Centre for Evolution and Cancer, The Institute of Cancer Research, London SW7 3RP, UK; nicola.valeri@icr.ac.uk

14 Department of Medicine, The Royal Marsden Hospital, London SW3 6JJ, UK

15 Oncology Unit, Casa di cura Igea, 20129 Milan, Italy; antonioghidini@hotmail.com

16 Oncology Unit, Medical Sciences Department, ASST Bergamo Ovest, 24047 Treviglio (BG), Italy

* Correspondence: faustopetrelli@gmail.com; Tel.: +39-0-363-424-420; Fax: +39-0-363-424-380

Received: 6 August 2020; Accepted: 27 August 2020; Published: 29 August 2020

check for updates

\begin{abstract}
The COVID-19 pandemic has inevitably caused those involved in cancer care to change clinical practice in order to minimize the risk of infection while maintaining cancer treatment as a priority. General advice during the pandemic suggests that most patients continue with ongoing therapies or planned surgeries, while follow-up visits may instead be delayed until the resolution of the outbreak. We conducted a literature search using PubMed to identify articles published in English language that reported on care recommendations for cancer patients during the COVID-19 pandemic from its inception up to 1st June 2020, using the terms "(cancer or tumor) AND (COVID 19)". Articles were selected for relevance and split into five categories: (1) personal recommendations of single or multiple authors, (2) recommendations of single authoritative centers, (3) recommendations of panels of experts or of multiple regional comprehensive centers, (4) recommendations of multicenter cooperative groups, (5) official guidelines or recommendations of health authorities. Of the $97 \mathrm{included}$ studies, 10 were personal recommendations of single or multiple independent authors, 16 were practice recommendations of single authoritative cancer centers, 35 were recommendations provided
\end{abstract}


by panel of experts or of multiple regional comprehensive centers, 19 were cooperative group position papers, and finally, 17 were official guidelines statements. The COVID-19 pandemic is a global emergency, and has rapidly modified our clinical practice. Delaying unnecessary treatment, minimizing toxicity, and identifying care priorities for surgery, radiotherapy, and systemic therapies must be viewed as basic priorities in the COVID-19 era.

Keywords: cancer; patients; treatment; COVID-19; pandemic

\section{Introduction}

Since the first report and identification of the responsible agent, the disease associated with the novel beta-coronavirus SARS-CoV2 (COVID-19) has spread globally, with an estimated 3.5 million cases and more than 20,000 deaths by end of April 2020. The explosion has been overwhelming, disrupting almost every healthcare system of involved countries and finding unprepared even those funded by robust economic resources. Healthcare professionals have suddenly seen the dawn of a completely new disease. COVID-19 has promptly been understood to be a "systemic disease" rather than a mere interstitial pneumonia.

Managing such a new clinical condition involves the challenge of dealing with both a lack of evidence and a lack of experience. However, unlike the previous HIV pandemic in the 80s, for the first time in the modern age we have had to face the problems of high volumes and an unprecedented rapidity of spread. Professionals from all specialties have suddenly found themselves being forced to become respiratory physicians, infectious disease specialists, and anesthetists; in this framework, the lack of knowledge in biology, epidemiology, pathophysiology, immune response, and treatment has highlighted the unmet need for uniformity and systematic review of current evidence.

Many national and international oncologic scientific societies have developed indications and guidelines for oncologists to follow in daily clinical practice. The aim of this review is to collect and discuss the current available guidelines and clinical practice recommendations for oncologists so far, as these professionals are faced with the challenge of continuing to deliver optimal care to cancer patients during the COVID-19 pandemic.

\section{Results}

\subsection{Personal Recommendations or Single Authoritative Center Statements}

Several local, national, and international recommendations for the management of cancer patients have emerged during the COVID-19 pandemic [1-16]. For example, there have been suggestions that surveillance should be delivered remotely for patients who have completed cancer treatment. In other cases, treatment might be deferred or completely avoided if the impact on quality of life is thought to be marginal. Only when treatment has a potentially curative role should it not be delayed. Examples are chemotherapy responsive tumors such as testicular, ovarian, and small cell lung cancers [4]. Moreover, a switch from intravenous to oral correspondent formulations (e.g., etoposide and vinorelbine) may be a valid indication [5]. Less intensive strategies are important especially in the cases of older and vulnerable patients. For example, in metastatic breast cancer patients, maintenance endocrine therapies after completing chemotherapy might represent a sound option in the elderly population. In general, older patients with cancer should not be systematically excluded from cancer treatments during COVID-19. However, it is worth noticing that, in case of COVID-19 infection and related complications during anticancer treatments, elderly patients are less likely to experience benefit from intensive unit admission and need for invasive mechanical ventilation highlighting the need for detailed upfront discussions about ceiling of care among oncologists, patients, and their families in this scenarios. 
Not only medical treatment but also surgical indications for cancer patients have been influenced by the COVID-19 pandemic. The Massachusetts General Hospital has proposed a multidisciplinary approach for triage of resectable patients. Using a virtual conference modality, the team identified five different profiles of patients suitable for oncologic surgery in a 7-10 day time frame. In particular, patients in the window of resectability after preoperative chemotherapy and cancer types with aggressive behaviors (e.g., triple negative breast cancer) are prioritized. In addition, diagnostic surgeries, second parts of staged procedures (after completion of the first part), and interventions due to onset of acute symptoms (e.g., gastrointestinal bleeding) are considered urgent and non-delayable [6]. In colorectal cancer surgery, a minimally invasive approach was suggested, with the prioritization of cancer-related emergencies (to be treated within 2 weeks). Conversely, a deferral period of up to 2 months was proposed in the case of surgeries for curable tumors. In early-stage disease, surgery could be deferred even later than 2 months from diagnosis [7]. Similarly, surgery for early-stage lung cancer was promoted both in stages I and IIa disease, the former with a low risk of progression and of COVID-19 infection, the latter with a high risk of progression and a low risk of infection. However, for stage $\mathrm{IIb}$ disease (low risk of progression but high risk of COVID-19 infection), conservative management with a follow-up up to 3 months before potential surgery is advisable. Finally, stage III disease, with a high risk of progression and of COVID-19 infection, requires specific medical treatments [8]. Among non-surgical therapies in lung cancer, adjuvant chemotherapy after surgery may be delayed up to 4 months after surgery without affecting patient survival. Chemotherapy with adjuvant and maintenance intent may be postponed or switched to oral formulation, while oral targeted drugs for patients with sensitive gene mutations should be administered without combination chemotherapy in order to avoid adverse events. As far as immunotherapy is concerned, treatment with checkpoint inhibitors has low immunosuppressive potential and avoiding it during a coronavirus infection may unfairly deprive these patients of an active class of drugs. However, special consideration should be given to patients suffering from immune-related adverse events because of their prolonged exposition to immunosuppressive agents, such as steroids [9]. On the whole, immunotherapy may be suspended or postponed in the case of stable disease and, generally, there is no need to administer it regularly during the epidemic period [10]. In non-small cell lung cancer, neoadjuvant chemotherapy for locally advanced resectable disease and sequential or concurrent chemoradiotherapy for stage III disease should be started when possible. In the advanced stages, first-line treatment and palliative or ablative radiotherapy outside the lung should not be delayed, either. Similarly, in small-cell lung cancer, both concurrent chemoradiotherapy and first-line therapy are both indicated with palliative or curative purposes [11].

In addition to medical and surgical treatment, radiation treatment should also be omitted or shortened in times of COVID-19 infection. Breast cancer experts from the Memorial Sloan Kettering Cancer Center in New York suggested the omission of radiotherapy in the case of ductal carcinoma in situ, in patients aged 70 and older, and in the case of invasive estrogen-receptor positive disease smaller than $3 \mathrm{~cm}$ in size without nodal involvement and with negative resection margins. However, in the cases of ductal carcinoma in situ with lesions bigger than $2.5 \mathrm{~cm}$, inadequate resection margins, or high-grade disease and in invasive estrogen-receptor positive tumors in younger patients, experts recommended a delay in treatment of 8-12 weeks after surgery. In general, hypofractionated or accelerated breast radiotherapy regimens are preferred in order to reduce treatment duration. High priority indications for breast radiotherapy are the diagnosis of inflammatory breast cancer and residual node positivity after neoadjuvant treatment, the presence of node-positive (N2) disease, recurrent disease, a diagnosis of triple negative node-positive disease, and extensive lymphovascular invasion [12].

In a pandemic phase with reduced availability of intensive/subintensive care beds, treatment strategies may prioritize medical treatment aimed at downstaging the disease until the peak of the pandemic has disappeared and the number of intensive care unit beds has increased. This approach is recommended in the treatment of ovarian cancer, where first-step surgery is preferred, especially in the 
case of otherwise healthy patients. In these unprecedented times, indications may be inverted and neoadjuvant chemotherapy could become the standard of care [13].

Management of cancers of the head and neck during a COVID-19 infection is an important matter to discuss because of the multidisciplinary features of management of these cancers. Moreover, patients with tracheostomy or total laryngectomy have a high risk of virus aerosolization and require special attention in terms of strategies to minimize the risks of infection [14]. Treatment of low-risk tumors like differentiated thyroid cancer should be delayed, with minimally invasive and transoral surgical approaches preferred over open and major surgery [15]. In the case of concomitant chemoradiotherapy indication for locally advanced disease, medical treatment should be omitted for patients who have comorbidities or who are older than 70. Similarly, sequential treatment with ciplatin-based induction chemotherapy should not be administered for these patients. Exclusive and definitive radiotherapy should be limited to simultaneous integrated boost techniques in the standard or accelerated schedule, in order to reduce treatment duration to 1 week, shorter than the sequential technique. In the case of salivary gland tumors, it is indicated to delay post-operative radiotherapy up to 12 weeks after surgery [15].

\subsection{Recommendations of Panels of Experts or Regional Cooperative Centers}

Different groups of experts tried to provide recommendations at a regional or more general level. For example, by describing the approach used to manage patients with cancer during a large-scale, respiratory syndrome-coronavirus hospital outbreak in Saudi Arabia in 2015, the authors offered a plan to help manage oncology services to prevent harm to patients or staff [16]. The plan focused on managing oncology services, infected patients, preventing any new infections in patients or staff, ensuring the continuity of cancer care, and incorporating measures to sustain these interventions far into the postoutbreak period.

Similarly, authors from Iran provided recommendations in order to limit the exposure of cancer patients to medical environments and to modify the treatment modalities in a manner that reduces the probability of myelosuppression. Such recommendations include delaying elective diagnostic and therapeutic services, shortening the treatment course, or prolonging the interval between treatment courses [17]. Specific precautions to prevent virus spread among cancer patients and cancer care providers were also suggested by Indian authors who additionally provided a table of myths and misinformation about COVID-19. This Table 1, based on advice published by the WHO, proved useful in mitigating panic in cancer patients [18]. 
Table 1. Characteristics of included studies.

\begin{tabular}{|c|c|c|c|c|c|}
\hline Author/Year & Journal & Country & Type of Study & Disease & Synthesis of Main Recommendations \\
\hline Ansarin/2020 & Acta Otorhinolaryngol Ital & Italy & $\begin{array}{l}\text { Personal view or } \\
\text { multi-authors review }\end{array}$ & $\mathrm{H} \& \mathrm{~N}$ & $\begin{array}{l}\text { Recommendations about surgery and compromise } \\
\text { between the necessary cancer treatments and the risk } \\
\text { of infection }\end{array}$ \\
\hline Banna/2020 & ESMO Open & Italy and Switzerland & $\begin{array}{l}\text { Personal view or } \\
\text { multi-authors review }\end{array}$ & Lung & $\begin{array}{l}\text { A decisional tool to support oncologists and } \\
\text { physicians in treatment for patients with lung cancer: } \\
\text { primum non nocere }\end{array}$ \\
\hline Cafarotti/2020 & J Thorac Oncol & Switzerland & $\begin{array}{c}\text { Personal view or } \\
\text { multi-authors review }\end{array}$ & Lung & $\begin{array}{l}\text { An algorithm of care to balance the risk of dying from } \\
\text { cancer or from potentially fatal infection }\end{array}$ \\
\hline Di Saverio/2020 & Colorectal Dis & Italy & $\begin{array}{l}\text { Personal view or } \\
\text { multi-authors review }\end{array}$ & Colorectal & $\begin{array}{l}\text { Management of patients needing surgery to mitigate } \\
\text { some risks and reduce exposure to other patients }\end{array}$ \\
\hline Falandry/2020 & J Geriatr Oncol & France & $\begin{array}{l}\text { Personal view or } \\
\text { multi-authors review }\end{array}$ & Various & $\begin{array}{l}\text { Challenges with the management of older patients } \\
\text { with cancer }\end{array}$ \\
\hline Kattan/2020 & Immunotherapy & France and Lebanon & $\begin{array}{l}\text { Personal view or } \\
\text { multi-authors review }\end{array}$ & Various & $\begin{array}{c}\text { A careful selection of the most efficacious anti-tumor } \\
\text { weaponry with the lower risk of weaning the patients' } \\
\text { immune system }\end{array}$ \\
\hline Mandato/2020 & Obstet Gynecol & Italy & $\begin{array}{l}\text { Personal view or } \\
\text { multi-authors review }\end{array}$ & Ovarian & $\begin{array}{l}\text { Finding new effective strategies in cancer care is } \\
\text { mandatory (allocate resources and real-life treatment) }\end{array}$ \\
\hline Schrag/2020 & JAMA & US & $\begin{array}{l}\text { Personal view or } \\
\text { multi-authors review }\end{array}$ & Various & $\begin{array}{c}\text { Planning for resuming cancer treatment and screening } \\
\text { to mitigate harms; changes will transform } \\
\text { cancer treatment }\end{array}$ \\
\hline Scotté/2020 & Eur J Cancer & France & $\begin{array}{l}\text { Personal view or } \\
\text { multi-authors review }\end{array}$ & Various & $\begin{array}{l}\text { Use of telemedicine for monitoring and optimizing } \\
\text { referral of Covid-19-positive patients with cancer } \\
\text { (CAPRI programme) }\end{array}$ \\
\hline Zhao/2020 & Thorac Cancer & China & $\begin{array}{l}\text { Personal view or } \\
\text { multi-authors review }\end{array}$ & Lung & $\begin{array}{l}\text { Recommendations and suggestions of individualized } \\
\text { treatment strategies and management of common } \\
\text { adverse events for patients with lung cancer }\end{array}$ \\
\hline Braunstein/2020 & Adv Radiat Oncol & US & $\begin{array}{l}\text { Single authoritative } \\
\text { center view }\end{array}$ & Breast & $\begin{array}{l}\text { The parsimonious application of breast radiotherapy } \\
\text { without compromising long term oncologic outcomes }\end{array}$ \\
\hline Davis/2020 & Immunotherapy & Australia & $\begin{array}{l}\text { Single authoritative } \\
\text { center view }\end{array}$ & Immunotherapy & $\begin{array}{l}\text { Suggestions about immunotherapy use } \\
\text { during pandemic }\end{array}$ \\
\hline De Felice/2020 & Radiother Oncol & Italy & $\begin{array}{l}\text { Single authoritative } \\
\text { center view }\end{array}$ & $\mathrm{H} \& \mathrm{~N}$ & $\begin{array}{l}\text { To offer adequate individualized treatment } \\
\text { recommendations based on both the epidemic } \\
\text { situation and the patient's own condition }\end{array}$ \\
\hline Gentileschi/2020 & Eur J Surg Oncol & Italy & $\begin{array}{l}\text { Single authoritative } \\
\text { center view }\end{array}$ & Skin & Skin cancer management \\
\hline
\end{tabular}


Table 1. Cont.

\begin{tabular}{|c|c|c|c|c|c|}
\hline Author/Year & Journal & Country & Type of Study & Disease & Synthesis of Main Recommendations \\
\hline Kligerman/2020 & Head Neck & US and Hong Kong & $\begin{array}{l}\text { Single authoritative } \\
\text { center view }\end{array}$ & $\mathrm{H} \& \mathrm{~N}$ & $\begin{array}{l}\text { To help minimize the risk of aerosolization and } \\
\text { SARS-CoV-2 exposures in head and neck cancer } \\
\text { patients with tracheostomy and TL }\end{array}$ \\
\hline Qadan/2020 & Ann Surg & US & $\begin{array}{l}\text { Single authoritative } \\
\text { center view }\end{array}$ & Various & $\begin{array}{l}\text { A multidisciplinary team approach for triage of } \\
\text { elective cancer surgery }\end{array}$ \\
\hline Salari/2020 & Oral Oncol & Iran & $\begin{array}{l}\text { Single authoritative } \\
\text { center view }\end{array}$ & $\mathrm{H} \& N$ & The role of virtual multidisciplinary team meetings \\
\hline Tagliaferri/2020 & $\begin{array}{l}\text { J Eur Acad Dermatol } \\
\text { Venereol }\end{array}$ & Italy & $\begin{array}{l}\text { Single authoritative } \\
\text { center view }\end{array}$ & Skin & Management of skin cancers during COVID-19 era \\
\hline Tasoulis/2020 & Eur J Surg Oncol & UK & $\begin{array}{l}\text { Single authoritative } \\
\text { center view }\end{array}$ & Breast & $\begin{array}{l}\text { Position of The Royal Marsden regarding breast } \\
\text { cancer surgery }\end{array}$ \\
\hline Wang/2020 & JAMA Oncol & China & $\begin{array}{l}\text { Single authoritative } \\
\text { center view }\end{array}$ & Various & $\begin{array}{l}\text { More attention should be paid to patients with cance } \\
\text { as a special population }\end{array}$ \\
\hline Thompson/2020 & Ann Surg & USA & $\begin{array}{l}\text { Single authoritative } \\
\text { center view }\end{array}$ & Breast & $\begin{array}{l}\text { Revised indication of neoadjuvant endocrine therapy } \\
\text { for the treatment of early stage estrogen receptor } \\
\text { positive breast cancer }\end{array}$ \\
\hline $\mathrm{Li} / 2020$ & Leukemia & China & $\begin{array}{l}\text { Single authoritative } \\
\text { center view }\end{array}$ & $\begin{array}{c}\text { Chronic myeloid } \\
\text { leukemia }\end{array}$ & $\begin{array}{l}\text { Questionnaires of subjects with chronic myeloid } \\
\text { leukemia during COVID-19 pandemic }\end{array}$ \\
\hline Sharma/2020 & Liver Int & UK & $\begin{array}{l}\text { Single authoritative } \\
\text { center view }\end{array}$ & $\begin{array}{l}\text { Hepatocellular } \\
\text { Cancer (HCC) }\end{array}$ & $\begin{array}{l}\text { Recommendations for the treatment of HCC during } \\
\text { COVID-19 pandemic }\end{array}$ \\
\hline Yerramilli/2020 & Adv Radiat Oncol & USA & $\begin{array}{l}\text { Single authoritative } \\
\text { center view }\end{array}$ & Various & $\begin{array}{l}\text { Use of hypofractionated radiation therapy for patients } \\
\text { requiring palliation for oncologic emergencies }\end{array}$ \\
\hline Valenza/2020 & Tumori & Italy & $\begin{array}{l}\text { Single authoritative } \\
\text { center view }\end{array}$ & Various & $\begin{array}{l}\text { Screening of patients accessing to a Comprehensive } \\
\text { Cancer Center with real-time PCR of nose-throat swabs }\end{array}$ \\
\hline Viale/2020 & Oncologist & Italy & $\begin{array}{l}\text { Single authoritative } \\
\text { center view }\end{array}$ & Breast & $\begin{array}{l}\text { Personalized strategies for optimal breast } \\
\text { cancer management }\end{array}$ \\
\hline Cakmak/2020 & Eur J Breast Health & Turkey & $\begin{array}{l}\text { Panel of experts or regional } \\
\text { recommendations }\end{array}$ & Breast & $\begin{array}{l}\text { Recommendations about timing of surgery of breast } \\
\text { cancer according to biology and risk }\end{array}$ \\
\hline Carneiro/2020 & Int Braz J Urol & Brazil & $\begin{array}{l}\text { Panel of experts or regional } \\
\text { recommendations }\end{array}$ & Urologic & $\begin{array}{l}\text { Suggestions and recommendations for the } \\
\text { management of urological conditions in times of } \\
\text { COVID-19 crisis in Brazil and other low- and } \\
\text { middle-income countries }\end{array}$ \\
\hline Cinar/2020 & J Natl Compr Canc Netw & US & $\begin{array}{l}\text { Panel of experts or regional } \\
\text { recommendations }\end{array}$ & Various & $\begin{array}{l}\text { Strategies to mitigate transmission of COVID-19 in an } \\
\text { effort to reduce morbidity and mortality associated } \\
\text { with the disease for patients with cancer and for the } \\
\text { healthcare workers }\end{array}$ \\
\hline
\end{tabular}


Table 1. Cont.

\begin{tabular}{|c|c|c|c|c|c|}
\hline Author/Year & Journal & Country & Type of Study & Disease & Synthesis of Main Recommendations \\
\hline Curigliano/2020 & Breast & International & $\begin{array}{l}\text { Panel of experts or regional } \\
\text { recommendations }\end{array}$ & Breast & $\begin{array}{l}\text { Advise on how to triage, prioritize, and organize } \\
\text { diagnostic procedures, surgical, radiation, and medical } \\
\text { treatments in breast cancer }\end{array}$ \\
\hline Dietz/2020 & Breast Cancer Res Treat & US & $\begin{array}{l}\text { Panel of experts or regional } \\
\text { recommendations }\end{array}$ & Breast & $\begin{array}{l}\text { Recommendations for prioritization, treatment and } \\
\text { triage of breast cancer patients during the } \\
\text { COVID-19 pandemic }\end{array}$ \\
\hline Ficarra/2020 & Minerva Urol Nefrol & Italy & $\begin{array}{l}\text { Panel of experts or regional } \\
\text { recommendations }\end{array}$ & Urologic & $\begin{array}{l}\text { Strategies for the reorganization of urological routine } \\
\text { practice and a set of recommendations to facilitate the } \\
\text { process of rescheduling surgical activity }\end{array}$ \\
\hline Finley/2020 & Can J Surg & Canada & $\begin{array}{l}\text { Panel of experts or regional } \\
\text { recommendations }\end{array}$ & Various & $\begin{array}{l}\text { Recommendations about cancer surgery by } \\
\text { Canadian surgeons }\end{array}$ \\
\hline $\begin{array}{l}\text { Head and Neck Surgery } \\
\text { Treatment Guidelines } \\
\text { Consortium/2020 }\end{array}$ & Head Neck & US & $\begin{array}{l}\text { Panel of experts or regional } \\
\text { recommendations }\end{array}$ & $\mathrm{H} \& N$ & $\begin{array}{l}\text { Head and Neck cancer treatment according to site and } \\
\text { stage of disease is presented }\end{array}$ \\
\hline Jazieh/2020 & JCO Glob Oncol & Saudi Arabia & $\begin{array}{l}\text { Panel of experts or regional } \\
\text { recommendations }\end{array}$ & Various & $\begin{array}{l}\text { It is important to have a robust mechanism to } \\
\text { prioritize patients to ensure the provision of timely } \\
\text { care while preventing further harm by guiding staff to } \\
\text { provide care in safety }\end{array}$ \\
\hline Koffman/2020 & Am J Hematol & US & $\begin{array}{l}\text { Panel of experts or regional } \\
\text { recommendations }\end{array}$ & CLL & $\begin{array}{l}\text { Recommendation about CLL treatment by a CLL panel } \\
\text { of experts }\end{array}$ \\
\hline Kowalski/2020 & Head Neck & International & $\begin{array}{l}\text { Panel of experts or regional } \\
\text { recommendations }\end{array}$ & $\mathrm{H} \& \mathrm{~N}$ & $\begin{array}{l}\text { Procedures essential to maintain safety of } \\
\text { otolaryngologists and maxillofacial surgeons exposed } \\
\text { to the greatest risk of infection }\end{array}$ \\
\hline Krengli/2020 & Adv Radiat Oncol & Italy & $\begin{array}{l}\text { Panel of experts or regional } \\
\text { recommendations }\end{array}$ & Various & $\begin{array}{l}\text { To adopt preventive measures and recommendations } \\
\text { for patients, professionals, and clinical operations to } \\
\text { minimize the risk of infection while safely treating } \\
\text { cancer patients }\end{array}$ \\
\hline Kutikov/2020 & Ann Intern Med & US & $\begin{array}{l}\text { Panel of experts or regional } \\
\text { recommendations }\end{array}$ & Various & $\begin{array}{l}\text { Risks must be balanced carefully, public health } \\
\text { strategies implemented thoroughly, and resources } \\
\text { utilized wisely }\end{array}$ \\
\hline Lalani/2020 & Can Urol Assoc J & Canada & $\begin{array}{l}\text { Panel of experts or regional } \\
\text { recommendations }\end{array}$ & Genitourinary & $\begin{array}{l}\text { Recommendations to assist in prioritizing systemic } \\
\text { therapies for patients with genitourinary cancers }\end{array}$ \\
\hline Lambertini/2020 & ESMO Open & Italy & $\begin{array}{l}\text { Panel of experts or regional } \\
\text { recommendations }\end{array}$ & Various & $\begin{array}{l}\text { Practical suggestions on how to implement cancer care } \\
\text { during the COVID-19 outbreak }\end{array}$ \\
\hline $\mathrm{Liu} / 2020$ & Indian J Surg & International & $\begin{array}{l}\text { Panel of experts or regional } \\
\text { recommendations }\end{array}$ & Various & $\begin{array}{l}\text { An approach for the management of surgical patients } \\
\text { in the context of the COVID-19 pandemic }\end{array}$ \\
\hline
\end{tabular}


Table 1. Cont

\begin{tabular}{|c|c|c|c|c|c|}
\hline Author/Year & Journal & Country & Type of Study & Disease & Synthesis of Main Recommendations \\
\hline Lou/2020 & JCO Oncol Pract & US & $\begin{array}{l}\text { Panel of experts or regional } \\
\text { recommendations }\end{array}$ & Gastrointestinal & $\begin{array}{l}\text { GI cancer treatment with the aim of minimizing } \\
\text { patient risk during pandemic }\end{array}$ \\
\hline Marijnen/2020 & Radiother Oncol & International & $\begin{array}{l}\text { Panel of experts or regional } \\
\text { recommendations }\end{array}$ & Rectal & $\begin{array}{l}\text { Radiotherapy treatment options for rectal cancer } \\
\text { during the COVID-19 pandemic }\end{array}$ \\
\hline Meattini/2020 & ESMO Open & Italy & $\begin{array}{l}\text { Panel of experts or regional } \\
\text { recommendations }\end{array}$ & Various & $\begin{array}{l}\text { Recommendations in order to keep cancer care as safe } \\
\text { as possible for both patients and healthcare providers }\end{array}$ \\
\hline Mohile/2020 & Neuro Oncol & International & $\begin{array}{l}\text { Panel of experts or regional } \\
\text { recommendations }\end{array}$ & Glioma & $\begin{array}{l}\text { To highlight opportunities to maximize the benefit and } \\
\text { minimize the risk of glioma management during this } \\
\text { pandemic and potentially, in the future }\end{array}$ \\
\hline Monk/2020 & Gynecol Oncol & US & $\begin{array}{l}\text { Panel of experts or regional } \\
\text { recommendations }\end{array}$ & Ovarian & $\begin{array}{l}\text { Recommendation about alternative routes of therapy } \\
\text { for ovarian cancer }\end{array}$ \\
\hline Motlagh/2020 & Arch Iran Med & Iran & $\begin{array}{l}\text { Panel of experts or regional } \\
\text { recommendations }\end{array}$ & Various & $\begin{array}{l}\text { Two limit the exposure of cancer patients to medical } \\
\text { environments, and modify the treatment modalities to } \\
\text { reduce the probability of myelosuppression (delaying } \\
\text { diagnostic and therapeutic services, shortening the } \\
\text { treatment course, or prolonging the interval between } \\
\text { treatment courses) }\end{array}$ \\
\hline $\mathrm{O}^{\prime}$ Cathail/2020 & Clin Oncol & UK & $\begin{array}{l}\text { Panel of experts or regional } \\
\text { recommendations }\end{array}$ & Anorectal & $\begin{array}{l}\text { Management of anorectal cancers provided by experts } \\
\text { of UK }\end{array}$ \\
\hline Patnaik/2020 & Am J Hematology & International & $\begin{array}{l}\text { Panel of experts or regional } \\
\text { recommendations }\end{array}$ & $\begin{array}{l}\text { Myelodisplastic/ } \\
\text { myeloproliferative } \\
\text { syndrome }\end{array}$ & $\begin{array}{c}\text { Recommendation about treatment by a panel } \\
\text { of experts }\end{array}$ \\
\hline Pino/2020 & JCO Glob Oncol & Colombia & $\begin{array}{l}\text { Panel of experts or regional } \\
\text { recommendations }\end{array}$ & Various & $\begin{array}{l}\text { Prioritization of adequate pathways for patients in } \\
\text { low- and middle-income settings is critical }\end{array}$ \\
\hline Pothuri/2020 & Gynecol Oncol & US & $\begin{array}{l}\text { Panel of experts or regional } \\
\text { recommendations }\end{array}$ & Gynecologic & $\begin{array}{l}\text { An expert panel convened to develop initial consensus } \\
\text { guidelines regarding anti-neoplastic therapy during } \\
\text { the COVID-19 pandemic with respect to gynecologic } \\
\text { cancer care and clinical trials }\end{array}$ \\
\hline Ramirez/2020 & Int J Gynecol Cancer & International & $\begin{array}{l}\text { Panel of experts or regional } \\
\text { recommendations }\end{array}$ & Gynecologic & $\begin{array}{l}\text { To share options in both the management and } \\
\text { surveillance of patients diagnosed with gynecologic } \\
\text { cancers during this time of global crisis }\end{array}$ \\
\hline Sarkissian/2020 & J Am Acad Dermatol & US & $\begin{array}{l}\text { Panel of experts or regional } \\
\text { recommendations }\end{array}$ & Dermatologic & $\begin{array}{c}\text { Recommendations regarding dermatological surgery } \\
\text { during COVID-19 pandemic }\end{array}$ \\
\hline Shankar/2020 & Asian Pac J Cancer Prev & International & $\begin{array}{l}\text { Panel of experts or regional } \\
\text { recommendations }\end{array}$ & Various & $\begin{array}{l}\text { Specific precautions for cancer patients and cancer care } \\
\text { providers to prevent spread }\end{array}$ \\
\hline Soran/2020 & Eur J Breast Health & US & $\begin{array}{l}\text { Panel of experts or regional } \\
\text { recommendations }\end{array}$ & Breast & $\begin{array}{l}\text { A consensus and a statement that may guide breast } \\
\text { care professionals (Magee-Breast Cancer Program) }\end{array}$ \\
\hline
\end{tabular}


Table 1. Cont.

\begin{tabular}{|c|c|c|c|c|c|}
\hline Author/Year & Journal & Country & Type of Study & Disease & Synthesis of Main Recommendations \\
\hline Teoh/2020 & World J Urol & EU & $\begin{array}{l}\text { Panel of experts or regional } \\
\text { recommendations }\end{array}$ & Bladder & Intravesical therapies recommendations \\
\hline Ueda/2020 & J Natl Compr Canc Netw & US & $\begin{array}{l}\text { Panel of experts or regional } \\
\text { recommendations }\end{array}$ & Various & $\begin{array}{c}\text { The importance of organizational structure, } \\
\text { preparation, agility, and a shared vision to provide } \\
\text { cancer treatment to patients in the face of uncertainty } \\
\text { and rapid change }\end{array}$ \\
\hline Wang/2020 & Crit Care & China & $\begin{array}{l}\text { Panel of experts or regional } \\
\text { recommendations }\end{array}$ & Various & Medical management strategies \\
\hline Werner/2020 & Otolaryngol Head Neck Surg & US & $\begin{array}{l}\text { Panel of experts or regional } \\
\text { recommendations }\end{array}$ & $\mathrm{H} \& \mathrm{~N}$ & $\begin{array}{l}\text { Care of cancer patients with head and neck cancers by } \\
\text { US experts }\end{array}$ \\
\hline $\mathrm{Wu} / 2020$ & Otolaryngol Head Neck Surg & International & $\begin{array}{l}\text { Panel of experts or regional } \\
\text { recommendations }\end{array}$ & $\mathrm{H} \& \mathrm{~N}$ & $\begin{array}{l}\text { Point of view about head and neck cancer treatment } \\
\text { during pandemic by Toronto and Wuhan hospitals }\end{array}$ \\
\hline Akladios/2020 & $\begin{array}{l}\text { J Gynecol Obstet Hum } \\
\text { Reprod }\end{array}$ & France & $\begin{array}{l}\text { Multicenter cooperative } \\
\text { groups }\end{array}$ & Gynecologic & $\begin{array}{l}\text { Recommendations about curative treatment of } \\
\text { cervical, ovarian and endometrial cancers according to } \\
\text { stage and risk groups }\end{array}$ \\
\hline Al-Shamsi/2020 & Oncologist & International & $\begin{array}{l}\text { Multicenter cooperative } \\
\text { groups }\end{array}$ & Various & $\begin{array}{l}\text { Consideration of risk and benefit for active } \\
\text { intervention in the cancer population during an } \\
\text { infectious disease pandemic must be individualized }\end{array}$ \\
\hline Ardura/2020 & $\begin{array}{l}\text { Biol Blood Marrow } \\
\text { Transplant }\end{array}$ & US & $\begin{array}{l}\text { Multicenter cooperative } \\
\text { groups }\end{array}$ & $\begin{array}{l}\text { Hematologic } \\
\text { cancers (stem cell } \\
\text { transplantation) }\end{array}$ & $\begin{array}{l}\text { Recommendations about hematopoietic stem cell } \\
\text { transplantation during COVID-19 }\end{array}$ \\
\hline Glehen/2020 & J Visc Surg & France & $\begin{array}{l}\text { Multicenter cooperative } \\
\text { groups }\end{array}$ & Peritoneal & $\begin{array}{l}\text { RENAPE and BIG-RENAPE guidelines for } \\
\text { peritoneal cancers }\end{array}$ \\
\hline Penel/2020 & Ann Oncol & France & $\begin{array}{l}\text { Multicenter cooperative } \\
\text { groups }\end{array}$ & Sarcoma & $\begin{array}{l}\text { General recommendations for the management of } \\
\text { sarcoma patients }\end{array}$ \\
\hline Thureau/2020 & J Bone Oncol & International & $\begin{array}{l}\text { Multicenter cooperative } \\
\text { groups }\end{array}$ & Bone metastasis & $\begin{array}{l}\text { The COVID-19 crisis requires a reorganization of the } \\
\text { health system, particularly in radiotherapy. A single } \\
\text { 8Gy fraction is recommended for most } \\
\text { clinical situations }\end{array}$ \\
\hline $\begin{array}{l}\text { Thoracic Surgery } \\
\text { Outcomes Research } \\
\text { Network/2020 }\end{array}$ & Ann Thorac Surg & US & $\begin{array}{l}\text { Multicenter cooperative } \\
\text { groups }\end{array}$ & Thoracic & $\begin{array}{l}\text { A document to offer guidance and to facilitate } \\
\text { decisions when caring for patients with thoracic } \\
\text { malignancies during the COVID-19 pandemic }\end{array}$ \\
\hline Whisenant/2020 & Cancer Cell & International & $\begin{array}{l}\text { Multicenter cooperative } \\
\text { groups }\end{array}$ & Thoracic Cancers & $\begin{array}{l}\text { Evaluation of the impact of COVID-19 infection in } \\
\text { patients with non-small cell lung cancer, small cell lung } \\
\text { cancer, mesothelioma, thymic epithelial tumors, and } \\
\text { thoracic carcinoid/neuroendocrine tumors. Thoracic } \\
\text { Cancers International COVID-19 collaboration }\end{array}$ \\
\hline
\end{tabular}


Table 1. Cont.

\begin{tabular}{|c|c|c|c|c|c|}
\hline Author/Year & Journal & Country & Type of Study & Disease & Synthesis of Main Recommendations \\
\hline Dingemans/2020 & J Thorac Oncol & International & $\begin{array}{l}\text { Multicenter cooperative } \\
\text { groups }\end{array}$ & Lung & $\begin{array}{l}\text { Multidisciplinary recommendations for the treatment } \\
\text { of lung cancer during COVID-19 pandemic }\end{array}$ \\
\hline Di Fiore/2020 & Dig Liver Dis & France & $\begin{array}{l}\text { Multicenter cooperative } \\
\text { groups }\end{array}$ & $\begin{array}{l}\text { Gastrointestinal } \\
\text { tumors }\end{array}$ & $\begin{array}{c}\text { Alternatives in the management of digestive cancers } \\
\text { during COVID-19 pandemic. Clinical point of view o } \\
\text { the French Intergroup }\end{array}$ \\
\hline Hungria/2020 & Hematol Transfus Cell Ther & Brazil & $\begin{array}{l}\text { Multicenter cooperative } \\
\text { groups }\end{array}$ & MM & $\begin{array}{l}\text { Recommendations for the treatment of MM during } \\
\text { COVID-19 pandemic. Recommendations from the } \\
\text { ABHH Monoclonal Gammopathies Committee }\end{array}$ \\
\hline Geskin/2020 & J Am Acad Dermatol & USA & $\begin{array}{l}\text { Multicenter cooperative } \\
\text { group }\end{array}$ & Skin & $\begin{array}{l}\text { Recommendations for the treatment of skin cancer } \\
\text { patients during COVID-19 pandemic }\end{array}$ \\
\hline Spolverato/2020 & Surgery & Italy & $\begin{array}{l}\text { Multicenter cooperative } \\
\text { group }\end{array}$ & $\begin{array}{l}\text { Surgical cancer } \\
\text { patients }\end{array}$ & Management of surgical patients with cancer \\
\hline De Azambuja/2020 & ESMO Open & EU & $\begin{array}{l}\text { Multicenter cooperative } \\
\text { group }\end{array}$ & Breast & $\begin{array}{l}\text { Recommendations for the treatment of breast cancer } \\
\text { patients during COVID-19 pandemic }\end{array}$ \\
\hline Catanese/2020 & ESMO Open & EU & $\begin{array}{l}\text { Multicenter cooperative } \\
\text { group }\end{array}$ & Pancreas & $\begin{array}{l}\text { Recommendations for the treatment of pancreatic } \\
\text { cancer patients during COVID-19 pandemic }\end{array}$ \\
\hline Jozaghi/2020 & Head Neck & USA & $\begin{array}{l}\text { Multicenter cooperative } \\
\text { group }\end{array}$ & Endocrine & $\begin{array}{l}\text { Recommendations for the treatment of endocrine } \\
\text { surgical cancer patients during COVID-19 pandemic }\end{array}$ \\
\hline Jereczek-Fossa/2020 & Clin Oncol & Italy & $\begin{array}{l}\text { Multicenter cooperative } \\
\text { group }\end{array}$ & Various & $\begin{array}{l}\text { Online questionnaires on how Lombardy radiotherapy } \\
\text { departments have coped with COVID-19 pandemic }\end{array}$ \\
\hline Van De Haar/2020 & Nat Med & $\mathrm{EU}$ & $\begin{array}{l}\text { Multicenter cooperative } \\
\text { group }\end{array}$ & Various & $\begin{array}{l}\text { A report on how seven comprehensive cancer centers } \\
\text { in EU have organized their healthcare systems during } \\
\text { COVID-19 pandemic }\end{array}$ \\
\hline Al-Rashdan/2020 & Adv Radiat Oncol & Canada & $\begin{array}{l}\text { Multicenter cooperative } \\
\text { group }\end{array}$ & Breast & $\begin{array}{l}\text { Use of hypo-fractionation and accelerated partial } \\
\text { breast irradiation for breast cancer during } \\
\text { COVID-19 pandemic }\end{array}$ \\
\hline Bartlett/2020 & Ann Surg Oncol & US & $\begin{array}{l}\text { Official guidelines or } \\
\text { health authorities' } \\
\text { recommendations }\end{array}$ & Various & $\begin{array}{l}\text { Considerations in management of cancer surgery cases } \\
\text { during the COVID-19 pandemic }\end{array}$ \\
\hline Bitar/2020 & Future Oncol & Lebanon & $\begin{array}{l}\text { Official guidelines or } \\
\text { health authorities' } \\
\text { recommendations }\end{array}$ & Various & $\begin{array}{l}\text { Recommendations for daily practice for the care of } \\
\text { cancer patients relate to prevention of contamination } \\
\text { prioritization of patients, avoiding overcrowded } \\
\text { clinics, ensuring the separation of oncology } \\
\text { departments from other units, and management of } \\
\text { palliative care patients }\end{array}$ \\
\hline
\end{tabular}


Table 1. Cont.

\begin{tabular}{|c|c|c|c|c|c|}
\hline Author/Year & Journal & Country & Type of Study & Disease & Synthesis of Main Recommendations \\
\hline Coles/2020 & Clin Oncol & International & $\begin{array}{l}\text { Official guidelines or } \\
\text { health authorities' } \\
\text { recommendations }\end{array}$ & Breast & $\begin{array}{l}\text { Recommendations where RT is minimized and } \\
\text { targeted to those with the highest risk of relevant } \\
\text { breast recurrence, to protect our patients and health } \\
\text { care professionals from potential exposure to } \\
\text { COVID-19 as well as reducing the workload for health } \\
\text { care providers and/or infrastructure }\end{array}$ \\
\hline Kimmig/2020 & J Gynecol Oncol & International & $\begin{array}{l}\text { Official guidelines or } \\
\text { health authorities' } \\
\text { recommendations }\end{array}$ & Gynecologic & $\begin{array}{l}\text { Robot assisted surgery (RAS) may help to reduce } \\
\text { hospital stay for patients that urgently need } \\
\text { complex-oncological-surgery, thus making room for } \\
\text { COVID-19 patients }\end{array}$ \\
\hline Ribal/2020 & Eur Urol & $\mathrm{EU}$ & $\begin{array}{l}\text { Official guidelines or } \\
\text { health authorities' } \\
\text { recommendations }\end{array}$ & Urologic & $\begin{array}{l}\text { Position of EAU and reporting of guidelines } \\
\text { recommendations during pandemic }\end{array}$ \\
\hline Thomson/2020 & Int J Radiat Oncol Biol Phys & International & $\begin{array}{l}\text { Official guidelines or } \\
\text { health authorities' } \\
\text { recommendations }\end{array}$ & $\mathrm{H} \& \mathrm{~N}$ & $\begin{array}{l}\text { This statement attempts to address the immediate } \\
\text { impacts of the COVID-19 pandemic on HNC clinical } \\
\text { practice. Practice recommendations for risk-adapted } \\
\text { head and neck cancer radiotherapy }\end{array}$ \\
\hline Troost/2020 & Radiother Oncol & $\mathrm{US}+\mathrm{EU}$ & $\begin{array}{l}\text { Official guidelines or } \\
\text { health authorities' } \\
\text { recommendations }\end{array}$ & Lung & ASTRO and ESTRO recommendations \\
\hline Von Lillenfeld-Toal/2020 & Leukemia & EU & $\begin{array}{l}\text { Official guidelines or } \\
\text { health authorities' } \\
\text { recommendations }\end{array}$ & Various & $\begin{array}{l}\text { EHA Infectious Disease Scientific Working Group } \\
\text { recommendations of cancer treatment }\end{array}$ \\
\hline Yahalom/2020 & Blood & International & $\begin{array}{l}\text { Official guidelines or } \\
\text { health authorities' } \\
\text { recommendations }\end{array}$ & Hematologic & $\begin{array}{l}\text { Recommendations for alternative radiation treatment } \\
\text { schemes: maintaining clinical efficacy and safety by } \\
\text { increasing the dose per fraction while reducing the } \\
\text { number of daily treatments }\end{array}$ \\
\hline You/2020 & Lancet Oncol & France & $\begin{array}{l}\text { Official guidelines or } \\
\text { health authorities' } \\
\text { recommendations }\end{array}$ & Various & $\begin{array}{c}\text { In a situation where available care facilities are scarce, } \\
\text { prioritization should involve the patients managed } \\
\text { with curative-intent therapeutic strategies, and those } \\
\text { with a life expectancy of } 5 \text { years or more, } \\
\text { acknowledging that final decisions lie with the } \\
\text { referring clinicians }\end{array}$ \\
\hline Zaorsky/2020 & Adv Radiat Oncol & US and UK & $\begin{array}{l}\text { Official guidelines or } \\
\text { health authorities' } \\
\text { recommendations }\end{array}$ & Prostate & $\begin{array}{l}\text { A RADS framework (Remote visits, and Avoidance, } \\
\text { Deferment, and Shortening of radiotherapy) was } \\
\text { created and applied to determine the appropriate } \\
\text { management for men with prostate cancer during the } \\
\text { global COVID-19 pandemic }\end{array}$ \\
\hline
\end{tabular}


Table 1. Cont.

\begin{tabular}{|c|c|c|c|c|c|}
\hline Author/Year & Journal & Country & Type of Study & Disease & Synthesis of Main Recommendations \\
\hline Chan/2020 & Support Care Cancer & USA/Canada/Australia & $\begin{array}{l}\text { Official guidelines or } \\
\text { health authorities' } \\
\text { recommendations }\end{array}$ & Various & $\begin{array}{l}\text { Three priority areas of survivorship care identified: } \\
\text { triage of immediate needs of cancer survivors, } \\
\text { tele-survivorship care, alternative models of care. A } \\
\text { qualitative survey of Multinational Association of } \\
\text { Supportive Care in Cancer (MASCC) Survivorship } \\
\text { Study Group }\end{array}$ \\
\hline Bergsland/2020 & Pancreas & USA & $\begin{array}{l}\text { Official guidelines or } \\
\text { health authorities' } \\
\text { recommendations }\end{array}$ & $\begin{array}{l}\text { Neuroendocrine } \\
\text { tumors } \\
\text { (NETs)/carcinomas } \\
\text { (NECs) }\end{array}$ & $\begin{array}{l}\text { Recommendations for the treatment of NETs/NECs } \\
\text { during COVID-19 pandemic: Official guidelines of the } \\
\text { North American Neuroendocrine Tumor Society }\end{array}$ \\
\hline Terpos/2020 & Leukemia & $\mathrm{EU}$ & $\begin{array}{l}\text { Official guidelines or } \\
\text { health authorities' } \\
\text { recommendations }\end{array}$ & $\begin{array}{l}\text { Multiple Myeloma } \\
\text { (MM) }\end{array}$ & $\begin{array}{l}\text { Recommendations for the treatment of MM during } \\
\text { COVID-19 pandemic: European Myeloma Network } \\
\text { (EMN) Consensus Paper }\end{array}$ \\
\hline Nguyen/2020 & Cancers & International & $\begin{array}{l}\text { Official guidelines or } \\
\text { health authorities' } \\
\text { recommendations }\end{array}$ & Various & $\begin{array}{l}\text { Practice proposal for the management of older cancer } \\
\text { patients during COVID-19 pandemic. Proposal of the } \\
\text { International Geriatric Radiotherapy Group }\end{array}$ \\
\hline Desideri/2020 & J Geriatr Oncol & International & $\begin{array}{l}\text { Official guidelines or } \\
\text { health authorities' } \\
\text { recommendations }\end{array}$ & Various & $\begin{array}{l}\text { Recommendations for the treatment of older cancer } \\
\text { patients during COVID-19 pandemic. Global } \\
\text { perspective of the Young International Society of } \\
\text { Geriatric Oncology (SIOG) }\end{array}$ \\
\hline Vecchione/2020 & ESMO Open & EU & $\begin{array}{l}\text { Official guidelines or } \\
\text { health authorities' } \\
\text { recommendations }\end{array}$ & Colorectal & $\begin{array}{l}\text { ESMO recommendations: redefinition of diagnostic } \\
\text { and therapeutic algorithms in colorectal cancer }\end{array}$ \\
\hline
\end{tabular}


Among the areas of China hardest hit by COVID-19 was Heilongiiang province. A series of protocols were established when the first confirmed case emerged, and authors summarized their experience in medical management strategies including protection of medical staff, reallocation of medical resources, plans for hierarchical treatment, and utilization of a network platform [19].

In an attempt to help cancer centers in low-resource settings, authors from Colombia created some adjusted recommendations such as (1) assuring social containment; (2) moving tumor boards and scientific meetings to virtual modalities; (3) changing of immunotherapy to 4 or 6 week schedules for selected patients, switching to oral therapies for advanced cases with intravenous treatments, and temporarily discontinuing noncritical therapies, such as bisphosphonates or denosumab; (4) using strict selection criteria for in-hospital chemotherapy. According to these authors, only potentially curative chemotherapy with severe toxicity profile should be delivered to inpatients for acute leukemias, high-grade lymphomas or soft tissue sarcomas [20].

Simple and straightforward guidance on decisions about immediate cancer treatment involving different treatment modalities (i.e., surgery, chemotherapy, and radiotherapy) during the COVID-19 crisis was also generated by Kutikov and colleagues from the Fox Chase Cancer Center [21]. Based on the risk for significant morbidity from COVID-19 (comorbidities need to be considered) and on the risk of cancer progression in case of treatment delay, patients were prioritized in disease groups to streamline clinical decisions and avoid deferral of treatment in specific high-risk groups.

Another panel of experts from the US reviewed strategies for mitigating the transmission of COVID-19 in an effort to reduce morbidity and mortality of cancer patients and healthcare workers [22].

Outside China, Italy had one of the largest COVID-19 outbreaks. Lambertini and colleagues offered practical and interesting suggestions on how to implement cancer care during the COVID-19 outbreak [23]. Their approach was summarized by the acronym YOP, which outlines priorities to protect: (1) Yourself (physicians) and their families, both at work and in their personal life, by following all official instructions, respecting lifestyle restrictions, and focusing on proper use and adequate stocks of personal protective equipment (PPE); (2) Oncological care of patients, by deferring what can be delayed but trying, as much as possible, to minimize the impact of the pandemic on the usual standard of care; (3) Patients themselves from being infected, by making any possible effort to minimize the risks and giving continuous direction and appropriate official information.

A number of experts tried to provide specific recommendations based on tumor subgroups. For example, leaders from the Magee Breast Cancer Program (from Surgery, Medical Oncology, Radiation Oncology, Plastic Surgery, Pathology, and Genetics) came to a consensus and prepared a statement that may guide breast care professionals in diagnosis, treatment, and follow-up during the COVID-19 pandemic [24]. Similarly, a panel of breast surgeons from Turkey highlighted the national and international approach to the crisis, and wrote a document to be used in routine clinical practice which may provide beneficial recommendations for breast surgery in the state of emergency [25]. Breast Journal panelists proposed how to triage, prioritize, and organize breast cancer cases during a COVID-19 outbreak [26]. Marijnen et al. provided recommendations for rectal cancer treatment using ESMO guidelines as a platform [27]. They encourage modulating treatments (from TME surgery alone to short course radiotherapy (RT) + neoadjuvant chemotherapy (CT) or CTRT for more advanced cases) and depict scenarios of various risk groups.

A further panel of experts provided suggestions and recommendations for the management of urological conditions during COVID-19 crisis in Brazil and other low- and middle-income countries. Specifically, the panel reached a consensus to prepare a practical guide for urologists based on the recommendations from the main Urologic Associations, as well from as data from the literature supporting the suggested management [28]. Additional recommendations on how to reorganize routine urological practice and prioritize systemic therapies for genitourinary malignancies came from Italy and USA, respectively [29,30]. Interestingly, the Editorial Team of the International Journal of Gynecological Cancer took the initiative to use established guidelines to prepare a practical tool in order to be able to propose strategies to optimize care of gynecological oncology patients [30]. 
Recommendations on dermatologic surgery during the COVID-19 pandemic were also published by experts from the UK who clearly stated that elective surgery such as the excision of benign lesions and cosmetic procedures should be postponed [31]. Conversely, patients with locally aggressive tumors (e.g., melanoma, dermatofibroma sarcoma protuberans, Merkel cell carcinoma, microcystic adnexal carcinoma) should proceed as soon as possible [31].

Finally, Italian radiation therapists provided recommendations on how to safely run a radiation oncology department and listed practical recommendations for radiation therapy during the COVID-19 outbreak, based on specific cancer care contexts [32,33]. Furthermore, a RADS framework (Remote visits, Avoidance, Deferment, and Shortening of radiotherapy) was created by an international panel of experts and applied to determine the appropriate management for prostate cancer during the global COVID-19 pandemic. Consensus was reached that all aspects of patient visits, treatment, and overall resource utilization can be reduced for all identified stages of prostate cancer treated with radiotherapy [34].

\subsection{Recommendations of Multicenter Cooperative Groups}

Al-Shamsi et al., on behalf of the International Collaborative Group, outlined various aspects of cancer care for patients being treated during the pandemic in a paper published in The Oncologist [35]. They discussed economic issues, allocation of resources, treatment of outpatients and hospitalized cancer patients, risk of infecting patients, and surgical considerations. In this exhaustive review, the authors addressed some of the current challenges associated with the managing of cancer patients during the COVID-19 pandemic and provided topical recommendations. In particular, lung cancer, hematopoietic stem cell transplantation, psychological aspects, and clinical research were discussed. Thureau et al., on behalf of the GEMO group (a European study group for bone metastases), discussed the topic of palliative RT for symptomatic bone metastases [36]. They indicated a single $8 \mathrm{~Gy}$ fraction as the recommended schedule for the palliation of bone pain. For spinal cord compression, surgical treatment should be prioritized whenever possible for all patients with a life expectancy of more than a few months. In cases where surgery is not indicated, exclusive RT may be indicated with a similar fractionation used for treating bone pain. Penel et al., on behalf of the French Sarcoma Group, briefly identified the major topics of sarcoma treatment [37]. In suspected COVID-19 cases, primary treatment should be postponed for at least 15 days after the symptoms start. Otherwise, all other treatment settings in COVID-19 negative patients should reflect the current practice.

The Consensus Statement from Thoracic Surgery Outcomes Research Network determined the ideal priorities for thoracic surgery in cancer patients [38]. They outlined situations that need immediate surgery (for staging, for symptomatic or node positive cancers, or after neoadjuvant therapy), delayed surgery (up to 3 months, for isolated lung nodules, thymomas or indolent histologies, for example), or alternative treatment modalities (as stereotactic body RT). When almost all hospital centers are dedicated to COVID-19, all cases except for those with perforated cancer of esophagus, septic patients, or patients with surgical complications may be reasonably delayed until after the pandemic has resolved.

Finally, the gynecological FRANCOGYN group discussed the topic of gynecological cancers during the pandemic [39]. They prefer neoadjuvant chemotherapy in stage III ovarian cancer with cytoreduction (without HIPEC) performed after six cycles. Cervical cancer can be managed with definitive CTRT to avoid surgical burden and low-risk endometrial cancers can be resected even after a 1-2 month waiting period.

\subsection{Official Guidelines or Recommendations of Health Authorities}

Several papers providing regional or international guidelines were published in these weeks [40-50]. Three were national guidelines ( $n=2$ French and $n=1$ Lebanese) and eight came from international societies. Four were RT guidelines (for lymphomas, head and neck, lung, and breast cancers), four were specific surgical guidelines ( $n=1$ gynecological, $n=1$ urological, $n=2$ head and 
neck malignancies), one discussed infection prevention, and one was the guidelines of the Society of Surgical Oncology (SSO). Finally, a European hematologist discussed prevention and treatment of cancer patients at risk of with COVID-19 infection.

The ILROG consensus was published by the International Society for Radiotherapy treatment in Lymphomas. They advised three possible strategies for RT delivery during the pandemic: omitting, delaying, and shortening the RT course. In particular, they consider omitting RT in the case of a palliative setting, localized low-grade lymphomas if completely excised, localized nodular lymphocyte-predominant Hodgkin lymphoma if wholly excised, and for consolidation RT for diffuse large B cell lymphomas/aggressive non Hodgkin lymphomas in patients who have completed the full $\mathrm{CT}$ course and achieved a complete remission.

Bartlett et al., on behalf of the SSO, briefly outlined the surgical indications for significant cancer types according to stage. Except for lung and gynecological cancers that were not part of these guidelines, they described surgical indications of the main cancer subtypes (breast, thyroid, abdominal, melanoma, and sarcoma). They endorse neoadjuvant therapies in many cases (breast, gastroesophageal, pancreatic, peritoneal, and high-grade sarcomas) with the deferral of resection procedures in many low-risk settings. Coles et al. reported on international guidelines for breast cancer RT. They reported five statements/recommendations regarding low-risk breast cancer, fractionation, elderly with ER+ breast cancer, boost necessity, and nodal RT.

A group of French authors published local recommendations for the protection of cancer patients from COVID-19 infection. They suggest minimizing hospital visits, using telemedicine and phone calls to replace safety visits, replacing intravenous drugs with oral drugs, and adjusting the dosage of CT and RT to reduce the frequency of hospital admissions. They list three treatment settings with reduced priority: (1) the curative setting, (2) the palliative (first line) setting for younger and fit patients or patients with at least 5 years of life expectancy, and (3) the palliative therapy setting in other cases.

ASTRO, ESTRO, and select Asia-Pacific countries provided head and neck RT guidelines through a modified rapid Delphi process. They reported agreement in many domains such as priority areas, treatment dose adjustment, RT delay, indications for surgery, and management of outpatients. Finally, Fakhry et al., on behalf of French societies for head and neck cancers, discussed surgical priorities in these patients. Group A refers to life-threatening emergencies (shortness of breath, hemorrhage) where immediate treatment is required, Group B refers to cancers for whom postponing the treatment beyond 1 month could have a negative prognostic impact for the patient and where management should not be delayed, and Group C refers to cancers for which treatment can be postponed for at least 6-8 weeks without any significant prognostic impact.

\section{Materials and Methods}

We conducted a literature search using PubMed to identify articles published in English language that reported on cancer patient care recommendations during the COVID-19 pandemic from inception up to 1st June 2020, using the terms "(cancer or tumor) AND (COVID-19)" (Table 1) [1-97].

Of the 97 included studies, 10 were personal recommendations of single or multiple independent authors, 16 were practice recommendations of single authoritative cancer centers, 35 were recommendations provided by panels of experts or by multiple regional cooperative centers, 19 were cooperative group position papers, and finally, 17 were official guidelines statements. The flow diagram of the included studies is reported in Figure 1. 

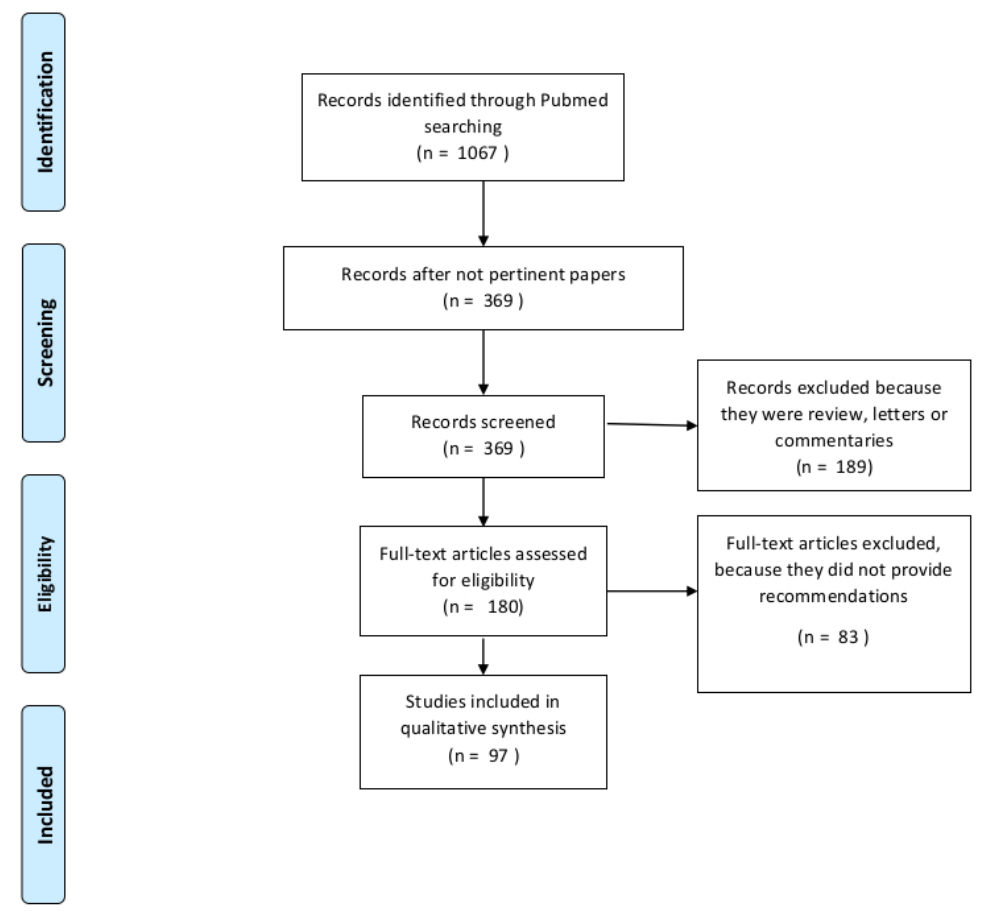

Figure 1. Flow diagram of included studies.

\section{Conclusions}

We systematically searched and collected all recommendations produced for cancer care during the COVID-19 pandemic era at various levels (personal view, single institution position, panel of experts, cooperative groups, and specific guidelines). Several aspects of treatment were discussed by the authors (surgery, CT, RT, supportive therapies) and these recommendations may judiciously guide care of patients in oncology setting during this worldwide emergency situation. The COVID-19 pandemic is a global emergency, and this has rapidly modified our clinical practice. Delaying of unnecessary treatment, minimizing the burden of toxicity, and identifying care priorities for surgery, radiotherapy, and systemic therapies settings must be viewed as basic priorities in the COVID-19 era and may shape cancer care services in the future.

Clinicians are aware about the various recommendations that are being provided for care of cancer from a local to an international point of view. International guidelines are probably less suitable for universal (worldwide) use. In fact, there are enormous differences between various countries and continents due to economic resources available, to the different evolution of the pandemic, to the presence or not of local (hub) high volume centers for the treatment of oncological pathologies, etc. In conclusion, we believe that oncologists, surgeons, and radiation oncologists should refer to the indications of their proper, national, scientific societies. The rapid evolution of epidemiology of pandemic, however, makes a continuous update of clinical practice guidelines, a necessity.

Author Contributions: Conceptualization, F.P. and G.T.; methodology, F.P.; software, F.P.; validation, M.G., F.G. and A.I. (Alice Indini); formal analysis, F.P.; investigation, F.T., A.I. (Alessandro Iaculli), L.D., G.M.; resources, A.Z.; data curation, F.P.; writing-original draft preparation, F.P., G.T., M.G., A.G.; writing-review and editing, A.R., I.V., A.B., E.R.; visualization, M.G.; supervision, N.V., L.B., F.G., D.D., A.Z., project administration, F.P.; funding acquisition, A.Z. All authors have read and agreed to the published version of the manuscript.

Funding: This research received no external funding.

Conflicts of Interest: The authors declare no conflict of interest. 


\section{References}

1. $\quad$ Lalani, A.-K.A.; Chi, K.N.; Heng, D.Y.; Kollmannsberger, C.K.; Sridhar, S.S.; Blais, N.; Canil, C.; Czaykowski, P.; Hotte, S.J.; Iqbal, N.; et al. Prioritizing systemic therapies for genitourinary malignancies: Canadian recommendations during the COVID-19 pandemic. Can. Urol. Assoc. J. 2020. [CrossRef] [PubMed]

2. Salari, A.; Shirkhoda, M. COVID-19 pandemic \& head and neck cancer patients management: The role of virtual multidisciplinary team meetings. Oral Oncol. 2020, 105, 104693. [PubMed]

3. Scotté, F.; Minvielle, E.; Mir, O.; André, F.; Barlesi, F.; Soria, J.-C. A patient reported outcome platform, a useful tool to improve monitoring and effective management of Covid-19-positive patients with cancer. Eur. J. Cancer 2020, 132, 1-4. [CrossRef] [PubMed]

4. Schrag, D.; Hershman, D.L.; Basch, E. Oncology practice during the COVID-19 pandemic. JAMA J. Am. Med. Assoc. 2020. [CrossRef] [PubMed]

5. Wang, Z.; Wang, J.; He, J. Active and effective measures for the care of patients with cancer during the COVID-19 spread in China. JAMA Oncol. 2020. [CrossRef]

6. Qadan, M.; Hong, T.S.; Tanabe, K.K.; Ryan, D.P.; Lillemoe, K.D. A multidisciplinary team approach for triage of elective cancer surgery at the massachusetts general hospital during the novel coronavirus COVID-19 outbreak. Ann. Surg. 2020. [CrossRef]

7. Di Saverio, S.; Pata, F.; Gallo, G.; Carrano, F.; Scorza, A.; Sileri, P.; Smart, N.; Spinelli, A.; Pellino, G. Coronavirus pandemic and colorectal surgery: Practical advice based on the Italian experience. Color. Dis. 2020. [CrossRef]

8. Cafarotti, S.; Patella, M.; Iosi, L.C.C. Lung cancer surgical management during the outbreak of COVID-19. J. Thorac. Oncol. 2020. [CrossRef]

9. Kattan, J.; Kattan, C.; Assi, T. Do checkpoint inhibitors compromise the cancer patients' immunity and increase the vulnerability to COVID-19 infection? Immunotherapy 2020, 19-22. [CrossRef]

10. Zhao, Z.; Bai, H.; Duan, J.; Wang, J. Recommendations of individualized medical treatment and common adverse events management for lung cancer patients during the outbreak of COVID-19 epidemic. Thorac. Cancer 2020. [CrossRef]

11. Banna, G.; Curioni-Fontecedro, A.; Friedlaender, A.; Addeo, A. How we treat patients with lung cancer during the SARS-CoV-2 pandemic: Primum non nocere. ESMO Open 2020, 5, e000765. [CrossRef]

12. Braunstein, L.Z.; Gillespie, E.F.; Hong, L.; Xu, A.; Bakhoum, S.F.; Cuaron, J.; Mueller, B.; McCormick, B.; Cahlon, O.; Powell, S.; et al. Breast radiotherapy under COVID-19 pandemic resource constraints-Approaches to defer or shorten treatment from a comprehensive cancer center in the United States. Adv. Radiat Oncol. 2020. [CrossRef] [PubMed]

13. Mandato, V.D.; Aguzzoli, L. Management of ovarian cancer during the COVID-19 pandemic. Int. J. Gynaecol. Obstet. 2020, 2-4. [CrossRef] [PubMed]

14. Ansarin, M. Surgical management of head and neck tumours during the SARS-CoV (Covid-19) pandemic. Acta Otorhinolaryngol Ital. 2020, 1-3. [CrossRef]

15. De Felice, F.; Polimeni, A.; Valentini, V. The impact of Coronavirus (COVID-19) on head and neck cancer patients' care. Radiother. Oncol. 2020, 147, 84-85. [CrossRef]

16. Jazieh, A.R.; Al Hadab, A.; Al Olayan, A.; Alhejazi, A.; Al Safi, F.; Al Qarni, A.; Farooqui, F.; Al Mutairi, N.; Alenazi, T.H. Managing oncology services during a major coronavirus outbreak: Lessons from the saudi arabia experience. JCO Glob. Oncol. 2020, 6, 518-524. [CrossRef] [PubMed]

17. Motlagh, A.; Yamrali, M.; Azghandi, S.; Azadeh, P.; Vaezi, M.; Ashrafi, F.; Zendehdel, K.; Mirzaei, H.; Basi, A.; Rakhsha, A.; et al. COVID19 prevention \& care; a cancer specific guideline. Arch. Iran. Med. 2020, 23, 255-264. [CrossRef]

18. Shankar, A.; Saini, D.; Roy, S.; Jarrahi, A.M.; Chakraborty, A.; Bharti, S.J.; Taghizadeh-Hesary, F. Cancer care delivery challenges amidst coronavirus disease -19 (covid-19) outbreak: Specific precautions for cancer patients and cancer care providers to prevent spread. Asian Pacific. J. Cancer Prev. 2020, 21, 569-573. [CrossRef]

19. Wang, H.; Wang, S.; Yu, K. COVID-19 infection epidemic: The medical management strategies in Heilongjiang Province, China. Crit. Care 2020, 24, 10-13. [CrossRef]

20. Pino, L.; Perez, C.; Cardona, A.; Triana, I. Cancer center recommendations to mitigate covid-19 impact in patients with cancer: Low-resource settings version. JCO Glob. Oncol. 2020, 6, 569-570. [CrossRef] 
21. Kutikov, A.; Weinberg, D.S.; Edelman, M.J.; Horwitz, E.M.; Uzzo, R.G.; Fisher, R.I. A war on two fronts: Cancer care in the time of COVID-19. Ann. Intern. Med. 2020, 172, 1-4. [CrossRef] [PubMed]

22. Cinar, P.; Kubal, T.; Freifeld, A.; Mishra, A.; Shulman, L.; Bachman, J.; Fonseca, R.; Uronis, H.; Klemanski, D.; Slusser, K.; et al. Safety at the time of the COVID-19 pandemic: How to keep our oncology patients and healthcare workers safe. J. Natl. Compr. Canc. Netw. 2020, 18, 1-6. [CrossRef] [PubMed]

23. Lambertini, M.; Toss, A.; Passaro, A.; Criscitiello, C.; Cremolini, C.; Cardone, C.; Loupakis, F.; Viscardi, G.; Meattini, I.; Dieci, M.V.; et al. Cancer care during the spread of coronavirus disease 2019 (COVID-19) in Italy: Young oncologists' perspective. ESMO Open 2020, 5, e000759. [CrossRef] [PubMed]

24. Soran, A.; Gimbel, M.; Diego, E. Breast cancer diagnosis, treatment and follow-up during COVID-19 pandemic. Eur. J. Breast Heal. 2020, 16, 86-88. [CrossRef]

25. Çakmak, G.K. Sars-CoV-2 (COVID-19) outbreak and breast cancer surgery in Turkey. Eur. J. Breast Health 2020, 16, 83-85. [CrossRef]

26. Curigliano, G.; Cardoso, M.J.; Poortmans, P.; Gentilini, O.; Pravettoni, G.; Mazzocco, K.; Houssami, N.; Pagani, O.; Senkus, E.; Cardoso, F.; et al. Recommendations for triage, prioritization and treatment of breast cancer patients during the COVID-19 pandemic. Breast 2020, 52, 8-16. [CrossRef]

27. Marijnen, C.; Peters, F.; Rödel, C.; Bujko, K.; Haustermans, K.; Fokas, E.; Glynne-Jones, R.; Valentini, V.; Spindler, K.-L.; Guren, M.; et al. International expert consensus statement regarding radiotherapy treatment options for rectal cancer during the COVID 19 pandemic. Radiother. Oncol. 2020. [CrossRef]

28. Carneiro, A.; Wroclawski, M.L.; Nahar, B.; Soares, A.; Cardoso, A.P.; Kim, N.J.; Carvalho, F.T. Impact of the COVID-19 pandemic on the urologist's clinical practice in Brazil: A management guideline proposal for lowand middle-income countries during the crisis period. Int. Braz. J. Urol. 2020, 46, 1-10. [CrossRef]

29. Ficarra, V.; Novara, G.; Abrate, A.; Bartoletti, R.; Crestani, A.; De Nunzio, C.; Giannarini, G.; Gregori, A.; Liguori, G.; Mirone, V.; et al. Urology practice during COVID-19 pandemic. Minerva. Urol. Nefrol. 2020. [CrossRef]

30. Ramirez, P.T.; Chiva, L.; Eriksson, A.G.Z.; Frumovitz, M.; Fagotti, A.; Martin, A.G.; Jhingran, A.; Pareja, R. COVID-19 global pandemic: Options for management of gynecologic cancers. Int. J. Gynecol. Cancer 2020. [CrossRef]

31. Der Sarkissian, S.A.; Kim, L.; Veness, M.; Yiasemides, E.; Sebaratnam, D.F. Recommendations on dermatologic surgery during the COVID-19 pandemic. J. Am. Acad Dermatol. 2020. [CrossRef] [PubMed]

32. Krengli, M.; Ferrara, E.; Mastroleo, F.; Brambilla, M.; Ricardi, U. Running a radiation oncology department at the time of coronavirus: An Italian experience. Adv. Radiat. Oncol. 2020. [CrossRef]

33. Meattini, I.; Franco, P.; Belgioia, L.; Boldrini, L.; Botticella, A.; De Santis, M.C.; Marvaso, G.; Montesi, G.; Parisi, S.; Triggiani, L.; et al. Radiation therapy during the coronavirus disease 2019 (covid-19) pandemic in Italy: A view of the nation's young oncologists. ESMO Open 2020, 5, 2019-2021. [CrossRef] [PubMed]

34. Zaorsky, N.G.; Yu, J.B.; McBride, S.M.; Dess, R.T.; Jackson, W.C.; Mahal, B.A.; Chen, R.; Choudhury, A.; Henry, A.; Syndikus, I.; et al. Prostate cancer radiotherapy recommendations in response to COVID-19. Adv. Radiat. Oncol. 2020. [CrossRef]

35. Al-Shamsi, H.O.; Alhazzani, W.; Alhuraiji, A.; Coomes, E.A.; Chemaly, R.F.; Almuhanna, M.; Wolff, R.A.; Ibrahim, N.K.; Chua, M.L.; Hotte, S.J.; et al. A practical approach to the management of cancer patients during the novel coronavirus disease 2019 (COVID-19) pandemic: An international collaborative group. Oncologist 2020, 2019, 1-10. [CrossRef] [PubMed]

36. Thureau, S.; Faivre, J.C.; Assaker, R.; Biver, E.; Confavreux, C.B.; Debiais, F.; Duterque-Coquillaud, M.; Giammarile, F.; Heymann, D.; Lecouvet, F.E.; et al. Adapting palliative radiation therapy for bone metastases during the Covid-19 pandemic: GEMO position paper. J. Bone Oncol. 2020. [CrossRef]

37. Penel, N.; Bonvalot, S.; Minard, V.; Orbach, D.; Gouin, F.; Corradini, N.; Brahmi, M.; Marec-Berard, P.; Briand, S.; Gaspar, N.; et al. French Sarcoma Group proposals for management of sarcoma patients during COVID-19 outbreak. Bull. Cancer 2020. [CrossRef]

38. Thoracic Surgery Outcomes Research Network, Inc. COVID-19 guidance for triage of operations for thoracic malignancies: A consensus statement from thoracic surgery outcomes research network. Ann. Thorac. Surg 2020. [CrossRef] 
39. Akladios, C.; Azais, H.; Ballester, M.; Bendifallah, S.; Bolze, P.-A.; Bourdel, N.; Bricou, A.; Canlorbe, G.; Carcopino, X.; Chauvet, P.; et al. Recommendations for the surgical management of gynecological cancers during the COVID-19 pandemic-FRANCOGYN group for the CNGOF. J. Gynecol. Obstet. Hum. Reprod. 2020, 101729. [CrossRef]

40. Bartlett, D.L.; Oncology, F.T.S.O.S.; Howe, J.R.; Chang, G.; Crago, A.; Hogg, M.; Karakousis, G.; Levine, E.; Maker, A.; Mamounas, E.; et al. Management of cancer surgery cases during the COVID-19 pandemic: Considerations. Ann. Surg. Oncol. 2020, 27, 1-4. [CrossRef]

41. Bitar, N.; Kattan, J.; Kourie, H.R.; Mukherji, D.; el Saghir, N. The Lebanese Society of Medical Oncology (LSMO) statement on the care of patients with cancer during the COVID-19 pandemic. Future Oncol. 2020, 16, 615-617. [CrossRef] [PubMed]

42. Coles, C.; Aristei, C.; Bliss, J.; Boersma, L.; Brunt, A.; Chatterjee, S.; Hanna, G.; Jagsi, R.; Person, O.K.; Kirby, A.; et al. International guidelines on radiation therapy for breast cancer during the COVID-19 Pandemic. Clin. Oncol. 2020, 32, 279-281. [CrossRef] [PubMed]

43. Fakhry, N.; Schultz, P.; Morinière, S.; Breuskin, I.; Bozec, A.; Vergez, S.; De Garbory, L.; Hartl, D.; Temam, S.; Lescanne, E.; et al. French consensus on management of head and neck cancer surgery during COVID-19 pandemic. Eur. Ann. Otorhinolaryngol. Head Neck Dis. 2020, 8-9. [CrossRef] [PubMed]

44. Kimmig, R.; Verheijen, R.H.M.; Rudnicki, M. Robot assisted surgery during the COVID-19 pandemic, especially for gynecological cancer: A statement of the Society of European Robotic Gynaecological Surgery (SERGS). J. Gynecol. Oncol. 2020, 31, 1-7. [CrossRef]

45. Thomson, D.J.; Palma, D.; Guckenberger, M.; Balermpas, P.; Beitler, J.J.; Blanchard, P.; Brizel, D.; Budach, W.; Caudell, J.; Corry, J.; et al. Practice recommendations for risk-adapted head and neck cancer radiation therapy during the COVID-19 pandemic: An ASTRO-ESTRO consensus statement. Int. J. Radiat. Oncol. Biol. Phys. 2020, 107, 618-627. [CrossRef]

46. Yahalom, J.; Dabaja, B.S.; Ricardi, U.; Ng, A.; Mikhaeel, N.G.; Vogelius, I.R.; Illidge, T.; Qi, S.; Wirth, A.; Specht, L. ILROG Emergency Guidelines for Radiation Therapy of Hematological Malignancies During the COVID-19 Pandemic. Blood 2020. [CrossRef]

47. You, B.; Ravaud, A.; Canivet, A.; Ganem, G.; Giraud, P.; Guimbaud, R.; Kaluzinski, L.; Krakowski, I.; Mayeur, D.; Grellety, T.; et al. The official French guidelines to protect patients with cancer against SARS-CoV-2 infection. Lancet Oncol. 2020, 2045, 20-21. [CrossRef]

48. Mohile, N.; Blakeley, O.J.; Gatson, N.T.N.; Hottinger, A.F.; Lassman, A.B.; Ney, E.D.; Olar, A.; Schiff, D.; Shih, A.H.; Strowd, R.; et al. Urgent considerations for the neuro-oncologic treatment of patients with gliomas during the COVID-19 pandemic. Neuro Oncol. 2020. [CrossRef]

49. Ribal, M.J.; Cornford, P.; Briganti, A.; Knoll, T.; Gravas, S.; Babjuk, M.; Harding, C.; Breda, A.; Bex, A.; Rassweiler, J.J.; et al. EAU section offices and the EAU guidelines panels. European association of urology guidelines office rapid reaction group: An organisation-wide collaborative effort to adapt the european association of urology guidelines recommendations to the coronavirus disease 2019. Era. Eur. Urol. 2020, 78, 21-28. [CrossRef]

50. Von Lilienfeld-Toal, M.; Vehreschild, J.J.; Cornely, O.; Pagano, L.; Compagno, F.; Hirsch, H.H.; Pagliuca, A. EHA Infectious Disease Scientific Working Group. Frequently asked questions regarding SARS-CoV-2 in cancer patients-recommendations for clinicians caring for patients with malignant diseases. Leukemia 2020. [CrossRef]

51. Chan, A.; Ashbury, F.; Fitch, M.I.; Koczwara, B.; Chan, R.J.; MASCC Survivorship Study Group. Cancer survivorship care during COVID-19-perspectives and recommendations from the MASCC survivorship study group. Support Care Cancer 2020, 28, 3485-3488. [CrossRef] [PubMed]

52. Ueda, M.; Martins, R.; Hendrie, P.C.; McDonnell, T.; Crews, J.R.; Wong, T.L.; McCreery, B.; Jagels, B.; Crane, A.; Byrd, D.R.; et al. Managing cancer care during the COVID-19 pandemic: Agility and collaboration toward a common goal. J. Natl. Compr. Canc. Netw. 2020, 18, 1-4. [CrossRef] [PubMed]

53. Kowalski, L.P.; Sanabria, A.; Ridge, J.A.; Ng, W.T.; De Bree, R.; Rinaldo, A.; Takes, R.P.; Mäkitie, A.A.; Carvalho, A.L.; Bradford, C.R.; et al. COVID-19 pandemic: Effects and evidence-based recommendations for otolaryngology and head and neck surgery practice. Head Neck 2020. [CrossRef] [PubMed]

54. Ma, C.H.M.S.; Vukkadala, N.; Tsang, R.K.Y.; Sunwoo, J.B.; Holsinger, F.C.; Chan, J.Y.K.; Damrose, E.J.; Kearney, A.; Starmer, H.M. Managing head and neck cancer patients with tracheostomy or laryngectomy during the COVID-19 pandemic. Head Neck 2020, 42, 1209-1219. [CrossRef] 
55. Liu, Z.; Zhang, Y.; Wang, X.; Zhang, D.; Diao, D.; Chandramohan, K.; Booth, C.M. Recommendations for surgery during the novel coronavirus (COVID-19) epidemic. Indian J. Surg. 2020, 1-5. [CrossRef]

56. Ardura, M.; Hartley, D.; Dandoy, C.; Lehmann, L.; Jaglowski, S.; Auletta, J.J. Transplant-Associated Learning Network Team (TALNT). Addressing the impact of the Coronavirus Disease 2019 (COVID-19) pandemic on hematopoietic cell transplantation: Learning networks as a means for sharing best practices. Biol. Blood Marrow Transpl. 2020. [CrossRef]

57. Davis, A.P.; Boyer, M.; Lee, J.H.; Kao, S. COVID-19: The use of immunotherapy in metastatic lung cancer. Immunotherapy 2020. [CrossRef]

58. Dietz, J.R.; Moran, M.S.; Isakoff, S.J.; Kurtzman, S.H.; Willey, S.C.; Burstein, H.J.; Bleicher, R.J.; Lyons, J.A.; Sarantou, T.; Baron, P.L.; et al. Recommendations for prioritization, treatment, and triage of breast cancer patients during the COVID-19 pandemic. The COVID-19 pandemic breast cancer consortium. Breast Cancer Res. Treat 2020. [CrossRef]

59. Finley, C.; Prashad, A.; Camuso, N.; Daly, C.; Aprikian, A.; Ball, C.G.; Bentley, J.; Charest, D.; Fata, P.; Helyer, L.; et al. Guidance for management of cancer surgery during the COVID-19 pandemic. Can. J. Surg. 2020, 63, S2-S4. [CrossRef]

60. Gentileschi, S.; Caretto, A.A.; Tagliaferri, L.; Salgarello, M.; Peris, K. Skin cancer plastic surgery during the COVID-19 pandemic. Eur. J. Surg. Oncol. 2020. [CrossRef]

61. Glehen, O.; Kepenekian, V.; Bouché, O.; Gladieff, L.; Honore, C.; Abba, J.; Abboud, K.; Arvieux, C.; Bakrin, N.; Delhorme, J.-B.; et al. Treatment of primary and metastatic peritoneal tumors in the Covid-19 pandemic. Proposals for prioritization from the RENAPE and BIG-RENAPE groups. J. Visc. Surg. 2020. [CrossRef] [PubMed]

62. Maniakas, A.; Jozaghi, Y.; Zafereo, M.E.; Sturgis, E.M.; Su, S.Y.; Gillenwater, A.M.; Gidley, P.W.; Lewis, C.M.; Diaz, E.; MD Anderson Head and Neck Surgery Treatment Guidelines Consortium; et al. Head and neck surgical oncology in the time of a pandemic: Subsite-specific triage guidelines during the COVID-19 pandemic. Head Neck 2020. [CrossRef]

63. Koffman, B.; Mato, A.R.; Byrd, J.C.; Danilov, A.; Hedrick, B.; Ujjani, C.; Roeker, L.; Stephens, D.M.; Davids, M.S.; Pagel, J.M.; et al. Management of CLL patients early in the COVID-19 pandemic: An international survey of CLL experts. Am. J. Hematol. 2020. [CrossRef]

64. Lou, E.; Beg, S.; Bergsland, E.; Eng, C.; Khorana, A.; Kopetz, S.; Lubner, S.; Saltz, L.; Shankaran, V.; Zafar, S.Y. Modifying practices in GI oncology in the face of COVID-19: Recommendations from expert oncologists on minimizing patient risk. JCO Oncol. Pract. 2020. [CrossRef]

65. Monk, B.J.; Coleman, R.L.; Moore, K.N.; Herzog, T.J.; Secord, A.A.; Matulonis, U.A.; Slomovitz, B.M.; Guntupalli, S.R.; O'Malley, D.M. COVID-19 and ovarian cancer: Exploring alternatives to intravenous (IV) therapies. Gynecol. Oncol. 2020. [CrossRef]

66. O'Cathail, S.; Gilbert, D.; Sebag-Montefiore, D.; Muirhead, R. Challenges and consequences of COVID-19 in the management of anorectal cancer: Coming together through social distancing. Clin. Oncol. 2020. [CrossRef] [PubMed]

67. Patnaik, M.; Lasho, T.; Padron, E.; McCullough, K.; Al-Kali, A.; Tefferi, A.; Zeidan, A.M.; Gangat, N.; Savona, M.; Steensma, D.P.; et al. Special considerations in the management of patients with myelodysplastic syndrome/myeloproliferative neoplasm overlap syndromes during the SARS-CoV-2 pandemic. Am. J. Hematol. 2020. [CrossRef]

68. Pothuri, B.; Secord, A.A.; Armstrong, D.K.; Chan, J.; Fader, A.N.; Huh, W.; Kesterson, J.; Liu, J.F.; Moore, K.; Westin, S.N.; et al. Anti-cancer therapy and clinical trial considerations for gynecologic oncology patients during the COVID-19 pandemic crisis. Gynecol. Oncol. 2020. [CrossRef]

69. Tagliaferri, L.; Di Stefani, A.; Schinzari, G.; Fionda, B.; Rossi, E.; Del Regno, L.; Gentileschi, S.; Federico, F.; Valentini, V.; Tortora, G. Skin cancer triage and management during COVID-19 pandemic. J. Eur. Acad. Dermatol. Venereol. 2020. [CrossRef]

70. Tasoulis, M.K.; Roche, N.; MacNeill, F. Rationalizing breast cancer surgery during the COVID-19 pandemic. Eur. J. Surg. Oncol. 2020. [CrossRef]

71. Teoh, J.Y.C.; Roupret, M.; Shariat, S.F.; Herrmann, T. Intravesical therapy for bladder cancer in the pandemic of Covid-19. World J. Urol. 2020. [CrossRef] [PubMed]

72. Troost, E.G.; Nestle, U.; Putora, P.M.; Bussink, J. Practice recommendations for lung cancer radiotherapy during the COVID-19 pandemic: An ESTRO-ASTRO consensus statement. Radiother. Oncol. 2020. [CrossRef] 
73. Werner, M.T.; Carey, R.M.; Albergotti, W.G.; Lukens, J.N.; Brody, R.M. Impact of the COVID-19 pandemic on the management of head and neck malignancies. Otolaryngol. Head Neck Surg. 2020. [CrossRef] [PubMed]

74. Wu, V.; Noel, C.W.; Forner, D.; Zhang, Z.; Higgins, K.M.; Enepekides, D.J.; Lee, J.M.; Witterick, I.J.; Kim, J.J.; Waldron, J.N.; et al. Considerations for head and neck oncology practices during the coronavirus disease 2019 (COVID-19) pandemic: Wuhan and Toronto experience. Head Neck 2020. [CrossRef] [PubMed]

75. Bergsland, E.K.; Halperin, D.M.; Dillon, J.S.; Dasari, N.A.; Kunz, P.L.; Soares, H.P.; Pryma, D.; Bodei, L.; Hope, T.; Soulen, M.C.; et al. North American neuroendocrine tumor society guide for neuroendocrine tumor patient health care providers during COVID-19. Pancreas 2020, 49, 723-728. [CrossRef] [PubMed]

76. Terpos, E.; Engelhardt, M.; Cook, G.; Gay, F.; Mateos, M.V.; Ntanasis-Stathopoulos, I.; van de Donk, N.W.C.J.; Avet-Loiseau, H.; Hajek, R.; Vangsted, A.J.; et al. Management of patients with multiple myeloma in the era of COVID-19 pandemic: A consensus paper from the European Myeloma Network (EMN). Leukemia 2020, 22, 1-12. [CrossRef] [PubMed]

77. Thompson, C.K.; Lee, M.K.; Baker, J.L.; Attai, D.J.; DiNome, M.L. Taking a second look at neoadjuvant endocrine therapy for the treatment of early stage estrogen receptor positive breast cancer during the COVID-19 outbreak. Ann. Surg. 2020. [CrossRef]

78. Nguyen, N.P.; Vinh-Hung, V.; Baumert, B.G.; Zamagni, A.; Arenas, M.; Motta, M.; Lara, P.C.; Myint, A.S.; Bonet, M.; Popescu, T.; et al. Older cancer patients during the COVID-19 epidemic: Practice proposal of the international geriatric radiotherapy group. Cancers 2020, 12, 1287. [CrossRef]

79. Li, W.-M.; Wang, D.; Guo, J.; Yuan, G.; Yang, Z.; Gale, R.P.; You, Y.; Chen, Z.; Chen, S.; Hubei Anti-Cancer Association; et al. COVID-19 in persons with chronic myeloid leukaemia. Leukemia 2020, 34, 1799-1804. [CrossRef]

80. Whisenant, J.G.; Trama, A.; Torri, V.; de Toma, A.; Viscardi, G.; Cortellini, A.; Micheilin, O.; Barlesi, F.; Dingemans, A.-M.C.; van Meerbeeck, J.; et al. TERAVOLT: Thoracic Cancers International COVID-19 Collaboration. Cancer Cell 2020, 37, 742-745. [CrossRef]

81. Sharma, R.; Pinato, D.J. Management of hepatocellular cancer in the time of SARS-CoV-2. Liver Int. 2020. [CrossRef] [PubMed]

82. Dingemans, A.-M.C.; Soo, R.A.; Jazieh, A.R.; Rice, S.J.; Kim, Y.T.; Teo, L.L.; Warren, G.W.; Xiao, S.-Y.; Smit, E.F.; Aerts, J.G.; et al. Treatment guidance for patients with lung cancer during the coronavirus 2019 pandemic. J. Thorac. Oncol. 2020, 15, 1119-1136. [CrossRef] [PubMed]

83. Viale, G.; Licata, L.; Sica, L.; Zambelli, S.; Zucchinelli, P.; Rognone, A.; Aldrighetti, D.; Di Micco, R.; Zuber, V.; Pasetti, M.; et al. Personalized risk-benefit ratio adaptation of breast cancer care at the epicenter of COVID-19 outbreak. Oncologist 2020. [CrossRef] [PubMed]

84. Di Fiore, F.; Thésaurus National de Cancérologie Digestive (TNCD); Société Nationale Française de Gastroentérologie (SNFGE); Fédération Francophone de Cancérologie Digestive (FFCD); Groupe Coopérateur multidisciplinaire en Oncologie (GERCOR); Fédération Nationale des Centres de Lutte Contre le Cancer (UNICANCER); Société Française de Chirurgie Digestive (SFCD); Société Française d'Endoscopie Digestive (SFED); Société Française de Radiothérapie Oncologique (SFRO) and Société Française de Radiologie (SFR); Association Chirurgie Hepato-Biliaire et Transplantation (ACHBT); et al. COVID-19 epidemic: Proposed alternatives in the management of digestive cancers: A French intergroup clinical point of view (SNFGE, FFCD, GERCOR, UNICANCER, SFCD, SFED, SFRO, SFR). Dig. Liver Dis. 2020, 52, 597-603. [CrossRef]

85. Hungria, V.; Garnica, M.; Crusoé, E.D.Q.; Filho, R.J.P.D.M.; Martinez, G.; Bittencourt, R.; de Farias, D.L.C.; Braga, W.M.; Neto, J.V.P.; Ribeiro, G.N.; et al. Managing patients with multiple myeloma during the COVID-19 pandemic: Recommendations from an expert panel-ABHH monoclonal gammopathies committe. Hematol. Transfus. Cell Ther. 2020. [CrossRef]

86. Desideri, I.; Pilleron, S.; Battisti, N.M.L.; Gomes, F.; De Glas, N.; Neuendorff, N.R.; Liposits, G.; Paredero-Pérez, I.; Lok, W.C.W.; Loh, K.P.; et al. Caring for older patients with cancer during the COVID-19 pandemic: A young international society of geriatric oncology (SIOG) global perspective. J. Geriatr. Oncol. 2020. [CrossRef]

87. Geskin, L.J.; Trager, M.H.; Aasi, S.Z.; Bickers, D.R.; Carvajal, R.D.; Nghiem, P.; Taback, B.; Zeitouni, N.C.; Samie, F.H. Perspectives on the recommendations for skin cancer management during the COVID-19 pandemic. J. Am. Acad. Dermatol. 2020, 83, 295-296. [CrossRef] 
88. Valenza, F.; Papagni, G.; Marchianò, A.; Daidone, M.G.; De’Braud, F.; Colombo, M.P.; Frignani, A.; Galmozzi, G.; Ladisa, V.; Pruneri, G.; et al. Response of a comprehensive cancer center to the COVID-19 pandemic: The experience of the fondazione IRCCS-istituto nazionale dei tumori di milano. Tumori 2020. [CrossRef]

89. Vecchione, L.; Stintzing, S.; Pentheroudakis, G.; Douillard, J.-Y.; Lordick, F. ESMO management and treatment adapted recommendations in the COVID-19 era: Colorectal cancer. ESMO Open 2020, 5 (Suppl. 3), e000826. [CrossRef]

90. Spolverato, G.; Capelli, G.; Restivo, A.; Bao, Q.R.; Pucciarelli, S.; Pawlik, T.M.; Gronchi, A. The management of surgical patients during the coronavirus disease 2019 (COVID-19) pandemic. Surgery 2020, 168, 4-10. [CrossRef]

91. De Azambuja, E.; Trapani, D.; Loibl, S.; Delaloge, S.; Senkus, E.; Criscitiello, C.; Poortman, P.; Gnant, M.; di Cosimo, S.; Cortes, J.; et al. ESMO management and treatment adapted recommendations in the COVID-19 era: Breast cancer. ESMO Open 2020, 5 (Suppl. 3), e000793. [CrossRef] [PubMed]

92. Catanese, S.; Pentheroudakis, G.; Douillard, J.Y.; Lordick, F. ESMO management and treatment adapted recommendations in the COVID-19 era: Pancreatic cancer. ESMO Open 2020, 5 (Suppl. 3), e000804. [CrossRef] [PubMed]

93. Jozaghi, Y.; Zafereo, M.E.; Perrier, N.D.; Wang, J.R.; Grubbs, E.; Gross, N.D.; Fisher, S.; Sturgis, E.M.; Goepfert, R.P.; Lai, S.Y.; et al. Endocrine surgery in the Coronavirus disease 2019 pandemic: Surgical triage guidelines. Head Neck 2020, 42, 1325-1328. [CrossRef] [PubMed]

94. Jereczek-Fossa, B.A.; Palazzi, M.F.; Soatti, C.P.; Cazzaniga, L.F.; Ivaldi, G.B.; Pepa, M.; Amadori, M.; Antognoni, P.; Arcangeli, S.; CODRAL (Board of Directors of Radiation Oncology Departments in Lombardy) Network. COVID-19 outbreak and cancer radiotherapy disruption in lombardy, Northern Italy. Clin. Oncol. 2020, 32, e160-e161. [CrossRef] [PubMed]

95. Van de Haar, J.; Hoes, L.R.; Coles, C.E.; Seamon, K.; Fröhling, S.; Jäger, D.; Valenza, F.; De Braud, F.; de Petris, L.; Bergh, J.; et al. Caring for patients with cancer in the COVID-19 era. Nat. Med. 2020, 26, 665-671. [CrossRef]

96. Yerramilli, D.; Xu, A.J.; Gillespie, E.F.; Shepherd, A.F.; Beal, K.; Gomez, D.; Yamada, J.; Tsai, C.J.; Yang, T.J. Palliative radiotherapy for oncologic emergencies in the setting of COVID-19: Approaches to balancing risks and benefits. Adv. Radiat. Oncol. 2020. [CrossRef] [PubMed]

97. Al-Rashdan, A.; Roumeliotis, M.; Quirk, S.; Grendarova, P.; Phan, T.; Cao, J.; Logie, N.; Smith, W.; Barbera, L. Adapting radiation therapy treatments for patients with breast cancer during the COVID-19 pandemic: Hypo-fractionation and accelerated partial breast irradiation to address world health organization recommendations. Adv. Radiat. Oncol. 2020. [CrossRef]

(C) 2020 by the authors. Licensee MDPI, Basel, Switzerland. This article is an open access article distributed under the terms and conditions of the Creative Commons Attribution (CC BY) license (http://creativecommons.org/licenses/by/4.0/). 